Dhaka Univ. J. Biol. Sci. 23(2): 197-204, 2014 (July)

\title{
DETECTION OF GIARDIA LAMBLIA IN CHILDREN BY MICROSCOPY, ELISA AND REAL TIME PCR ASSAY
}

\author{
Tahmina Ahmed ${ }^{1}$, Hamida Khanum*, Priyanka Barua ${ }^{1}$, Tuhinur Arju${ }^{1}$, \\ Muhammed Salah Uddin ${ }^{1}$ and Rashidul Haque ${ }^{1}$ \\ Department of Zoology, University of Dhaka, Dhaka-1000, Bangladesh
}

Key words: ELISA, Real time PCR, Giardia lamblia, Prevalence

\begin{abstract}
Conventional microscopy, ELISA and Real Time PCR showed Giardia lamblia in a total of 4470 asymptomatic and 423 symptomatic faecal samples from urban slum children of 13 - 60 months age old. ELISA showed more sensitivity $(88.88 \%)$ and specificity (90.91\%) than microscopy (6.5\% sensitive and $100 \%$ specific). The prevalence of G. lamblia infection among asymptomatic children was $37.93 \%$ by microscopy and $76.11 \%$ by ELISA. The prevalence was $7.03,38.91$ and 66.49 by microscopy, ELISA and Real Time PCR in symptomatic children, respectively. The highest prevalence $(80.95 \%)$ of infection was found in symptomatic children between 49 and 60 months old. Peak prevalence among asymptomatic children was found in March, 2012 (39.39\%) and among symptomatic children in September, 2012 (88.88\%). Giardia lamblia infection was higher (71.03\%) in male than in female children $(60.26 \%)$.
\end{abstract}

\section{Introduction}

The WHO ranks diarrhoea disease as the second most common cause of morbidity and mortality in children in the developing countries ${ }^{(1)}$. Giardia lamblia is the most common protozoan infection of the intestinal tract and considered as one of the main causes of diarrhoea in developed countries ${ }^{(2)}$. G. lamblia infection is transmitted by the fecal-oral route and cause giardiasis. Children who live in crowded conditions or poor socioeconomic areas are the risk group for G. lamblia infection. Interestingly, most of them are asymptomatic and can shed the Giardia cysts in the environment. Thus, the diagnosis of G. lamblia infection in asymptomatic infection plays an important role in achieving control and transmission ${ }^{(3)}$. Clinical manifestation ranges from asymptomatic carriage to acute and chronic gastrointestinal infections ${ }^{(4)}$. The clinical manifestations of symptomatic giardiasis include greasy stools, flatulence, diarrhea, abdominal cramps, epi-gastric tenderness and mal-absorption ${ }^{(5)}$.

In developing countries, about 200 million people have symptomatic giardiasis with some 500,000 new cases reported each year ${ }^{(6)}$. The disease is most common in areas where sanitation and hygiene are poor ${ }^{(7)}$. Higher prevalence is found in tropical and subtropical

*Author for correspondence. ${ }^{1}$ International Centre for Diarrheal Disease Research, Bangladesh (ICDDR, B), Mohakhali, Dhaka, Bangladesh. 
areas, in urban than in rural where G. lamblia affects up to $30 \%$ of the population ${ }^{(8,9)}$. Haque et al. reported $11.08 \%$ G. lamblia infection in 2 - 5 year-age group in Mirpur, Dhaka ${ }^{(10)}$.

In Bangladesh several studies have been carried out to determine the prevalence of G. lamblia by direct microscopic examination ${ }^{(10,11)}$. There is a need for a sensitive and specific diagnostic techniques like immunofluorescence assay, enzyme-linked immunosorbent assay (ELISA) or polymerase chain reaction (PCR) for screening G. lamblia. ELISA has greater sensitivity and specificity than the conventional diagnostic techniques ${ }^{(12)}$.

GIARDIA ELISA is a monoclonal ELISA for detecting G. lamblia antigen in the feces. Detection of G. lamblia and antigen by GIARDIA ELISA (Techlab, Blacksburg, VA) provides an alternative method of establishing a diagnosis which is sensitive and specific(13). Recently, Real Time PCR, a new methodology that uses fluorescent labels to enable continuous monitoring of amplicon (PCR product) formation throughout the reaction, has recently been adapted to detect parasites. Attempt has been made to determine the prevalence of G. lamblia infection in children using ELISA and Real Time PCR.

\section{Materials and Methods}

The present study was carried out during January, 2012 to Decembe, 2012 in the Parasitology Laboratory, at the International Centre for Diarrhoeal Disease Research, Bangladesh (ICDDR, B). The study area was a slum area of Mirpur, Dhaka. A total of 406 children were examined for the study. Age range of the children was 13 - 60 months. From each of the 406 children, one normal (asymptomatic) stool was collected in every month. Diarrhoeal stool samples of 423 children were collected and examined whenever they had diarrhoeal episode. The samples were stored at $-20^{\circ} \mathrm{C}$. Information about the age, sex, clinical signs and symptoms and date of collection was recorded. Microscopic examination was done by direct smear. The GIARDIA ELISA (Techlab, Blacksburg, VA) was used for the detection of G. lamblia from all samples and Real Time PCR assay was used for the detection of the parasite from symptomatic samples. The tests were performed according to the manufacturer's instructions.

Enzyme Linked Immunosorbent Assay (ELISA) utilizes an antibody labeled with an enzyme marker such as horseradish peroxides. The Giardia test uses monoclonal and polyclonal antibodies to a cell-surface of the organism. The microtiter wells in the kit contained immobilized monoclonal antibody and the detecting antibody with polyclonal antibody, both of which were specific for the cell surface antigen. In the assay, an aliquot of a diluted fecal specimen was transferred to a microtiter well. If the Giardia antigen was present, it binds to the immobilized monoclonal antibody. When the detecting antibody was added, it binds to the antigen/antibody complex. The bound detecting antibody was detected using an anti-rabbit IgG-peroxidase conjugate. Any unbound materials were 
removed during the washing steps. Following the addition of substrate, a color was detected due to the enzyme-antibody-antigen complexes that formed in the presence of Giardia antigen.

For G. lamblia, $0.2 \mathrm{~g}$ of stool sample was used for extraction of DNA. For the QIAamp method, the stool was subjected to six freeze-thaw cycles in liquid nitrogen and a $95^{\circ} \mathrm{C}$ water bath. DNA was extracted using the QIAamp DNA stool mini kit (QIAGEN, Hilden, Germany) according to the manufacturer's instructions except that the suspension was incubated in the kit's stool lysis buffer at $95^{\circ} \mathrm{C}$, and a 3-minute incubation with the InhibitEX tablets was used. The DNA was eluted in $0.2 \mathrm{ml}$ of AE buffer (supplied with the QIAGEN kit).

Amplification reactions were performed in a volume of $25 \mu \mathrm{l}$ with Qiagen master mix (containing $100 \mathrm{mmol} / \mathrm{l} \mathrm{KCL} ; 40 \mathrm{mmol} / \mathrm{l}$ tris- $\mathrm{HCl}$, pH 8.4; $1.6 \mathrm{mmol} / \mathrm{l}$ deoxynucleoside triphosphate; iTaq DNA polymerase [50 units/ml], $2 \mathrm{mmol} / 1 \mathrm{MgCl} 2$ ) and an additional 3 $\mathrm{mmol} / 1 \mathrm{MgCl} 2$ also added; $0.4 \mu \mathrm{mol} / \mathrm{l}$ of each Gd-80F, Gd-127R primers and $0.12 \mu \mathrm{mol} / \mathrm{l}$ of Gd-FT probes for G. lamblia and $3 \mu \mathrm{l}$ of the DNA sample were used in each reaction. Amplification consisted of 3 minutes at $95^{\circ} \mathrm{C}$ followed by 45 cycles of 30 seconds at $95^{\circ} \mathrm{C}$, 30 seconds at $55^{\circ} \mathrm{C}$, and 30 seconds at $72^{\circ} \mathrm{C}$. Amplification, detection, and data analysis were performed with the i-Cycler real-time detection system (BioRad). Fluorescence was measured during the annealing step of each cycle. The ramping of the machine was $3.3^{\circ} \mathrm{C} / \mathrm{sec}$ in every step. Fluorescence at $490 \mathrm{~nm}$ was measured for G. lamblia. Data were analyzed by using Microsoft Excel and SPSS software.

\section{Results and Discussion}

Out of 406 children, a total of 4893 fecal samples were collected and examined. The asymptomatic samples were collected in every month, and symptomatic samples were also collected when children had a diarrhoeal episode. The number of asymptomatic and symptomatic samples were 4470 and 423 , respectively. The prevalence of G. lamblia infection among asymptomatic children was $37.93 \%$ by microscopy and $76.11 \%$ by ELISA. That value was $7.03,38.91$ and $66.49 \%$ by microscopy, ELISA and Real Time PCR in symptomatic children, respectively (Table 1 ).

Sex wise distribution of G. lamblia infection in children (Tables 2, 3) revealed that males were at higher risk for developing infection compared to females in both asymptomatic and symptomatic condition $(p=0.214)$. The difference was, however, not significant $(\mathrm{p}=0.214)$.

In total sample, microscopic examination was $6.5 \%$ sensitive and $100 \%$ specific. ELISA was $88.88 \%$ sensitive and $90.91 \%$ specific. The present study highlights the lack of sensitivity of direct microscopy technique that are commonly used in most diagnostic laboratories provide for diagnosis of Giardia sp. infection. The result was comparable with Aldeen et al. who found that Giardia ELISA shows 91\% sensitivity and $98 \%$ 
specificity ${ }^{(14)}$. Interestingly, most Giardia-positive cases in this study were asymptomatic and/or show Giardia cysts in stool samples. In some liquid stools were however, Giardiapositive by microscopy. This is attributable to the fact that liquid stools are diluted and difficult to examine microscopically(15).

Table 1. Comparative prevalence of Giardia lamblia in children by microscopy, ELISA and Real Time PCR.

\begin{tabular}{lcccc}
\hline $\begin{array}{l}\text { Type of } \\
\text { infection }\end{array}$ & $\begin{array}{c}\text { Number of } \\
\text { children } \\
\text { examined }\end{array}$ & $\begin{array}{c}\text { Prevalence by } \\
\text { microscopy (\%) }\end{array}$ & $\begin{array}{c}\text { Prevalence by } \\
\text { ELISA (\%) }\end{array}$ & $\begin{array}{c}\text { Prevalence by } \\
\text { Real Time } \\
\text { PCR (\%) }\end{array}$ \\
\hline $\begin{array}{l}\text { Asymptomatic } \\
\text { Symptomatic }\end{array}$ & 406 & 37.93 & 76.11 & - \\
\hline
\end{tabular}

Table 2. Comparative prevalence of Giardia lamblia in different sex groups in asymptomatic sample by microscopy and ELISA.

\begin{tabular}{lccc}
\hline Sex & $\begin{array}{c}\text { Number of children } \\
\text { examined }\end{array}$ & $\begin{array}{c}\text { Prevalence by microscopy } \\
(\%)\end{array}$ & $\begin{array}{c}\text { Prevalence by ELISA } \\
(\%)\end{array}$ \\
\hline Male & 221 & 41.62 & $76.92^{\mathrm{a}}$ \\
Female & 185 & 33.51 & $75.13^{\mathrm{a}}$ \\
\hline
\end{tabular}

$\chi^{2} \mathrm{p}$ value: ${ }^{\mathrm{a}} \mathrm{p}=0.027$ (G. lamblia infection was significantly higher in male than female).

Table 3. Comparative prevalence of Giardia lamblia in different sex groups in symptomatic sample by microscopy, ELISA and Real time PCR.

\begin{tabular}{lcccc}
\hline Sex & $\begin{array}{c}\text { Number of } \\
\text { children examined }\end{array}$ & $\begin{array}{c}\text { Prevalence by } \\
\text { microscopy }(\%)\end{array}$ & $\begin{array}{c}\text { Prevalence by } \\
\text { ELISA }(\%)\end{array}$ & $\begin{array}{c}\text { Prevalence by Real } \\
\text { time PCR (\%) }\end{array}$ \\
\hline Male & 107 & 5.6 & $43^{\mathrm{b}}$ & $71.03^{\mathrm{a}}$ \\
Female & 78 & 8.97 & $33.33^{\mathrm{b}}$ & $60.26^{\mathrm{a}}$ \\
\hline
\end{tabular}

$\chi^{2} \mathrm{p}$ value: ${ }^{\mathrm{a}} \mathrm{p}=0.214 ;{ }^{\mathrm{b}} \mathrm{p}=0.328$ (G. lamblia infection was higher in male than female, but it was not significant).

The prevalence of G. lamblia infection was highest (42.86\%) in symptomatic children between 49 - 60 months of age. In asymptomatic children high prevalence (35.18\%) was found at the age group 25 - 36 months, and in 49 - 60 months age group (Tables 4, 5) the prevalence was lowest $(6.76 \%)(\mathrm{p}<0.001)$.

Monthly prevalence of G. lamblia in asymptomatic children showed high prevalence in March (39.39\%) and June (31.62\%); it gradually decreased and showed lowest prevalence in December $(9.28 \%)(\mathrm{p}<0.001)$. Monthly data of symptomatic children showed higher prevalence in Sept. $(88.88 \%)$ and Nov. $(81.58 \%)$ (Figs 1, 2) $(\mathrm{p}<0.001)$. 
Table 4. Prevalence of Giardia lamblia infection in different age groups in asymptomatic sample by ELISA.

\begin{tabular}{lccc}
\hline $\begin{array}{l}\text { Age group } \\
\text { (Months) }\end{array}$ & $\begin{array}{c}\text { Number of sample } \\
\text { examined }\end{array}$ & $\begin{array}{c}\text { Number of positive } \\
\text { sample }\end{array}$ & Percentage \\
\hline $13-24$ & 702 & 212 & 30.20 \\
$25-36$ & 1498 & 527 & 35.18 \\
$37-48$ & 1485 & 259 & 17.44 \\
$49-60$ & 784 & 53 & 6.76 \\
\hline
\end{tabular}

$\chi^{2} \mathrm{p}$ value: $\mathrm{p}<0.001$

Table 5. Prevalence of Giardia lamblia infection in different age groups in symptomatic sample by Real time PCR.

\begin{tabular}{lccc}
\hline $\begin{array}{l}\text { Age group } \\
\text { (Months) }\end{array}$ & $\begin{array}{c}\text { Number of sample } \\
\text { examined }\end{array}$ & $\begin{array}{c}\text { Number of positive } \\
\text { sample }\end{array}$ & Percentage \\
\hline $13-24$ & 158 & 75 & 47.46 \\
$25-36$ & 166 & 80 & 48.19 \\
$37-48$ & 78 & 42 & 53.84 \\
$49-60$ & 21 & 17 & 80.95 \\
\hline
\end{tabular}

$\chi^{2} p$ value: $p=0.047$

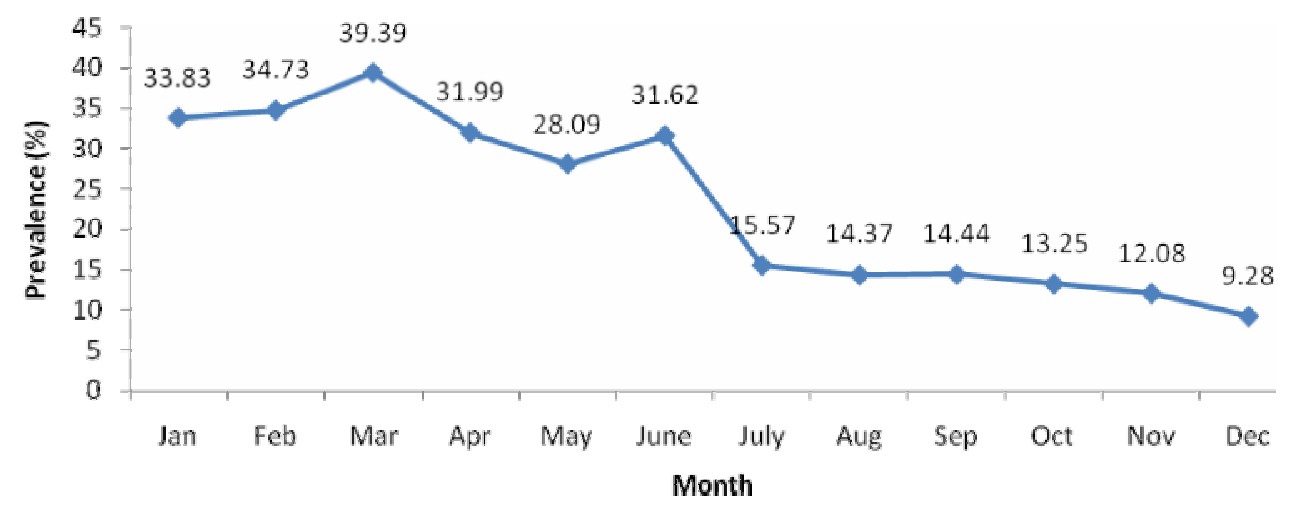

Fig. 1. Monthly prevalence of Giardia lamblia in asymptomatic children by ELISA.

In the present study, the prevalence of G. lamblia was $76.11 \%$ in asymptomatic children by ELISA, and $66.49 \%$ in symptomatic children by Real Time PCR assay. Haque et al. reported $11 \%$ prevalence in children by ELISA ${ }^{(10)}$. Overcrowding, lack of personal hygiene and sanitary conditions of the area, contaminated drinking water, are thought to be responsible for higher prevalence of infections. However, the prevalence obtained by the present study was not consistent with those of the previous studies(16,17). This difference may be due to sample size and diagnostic techniques. Studies in India and 
Nigeria have shown that boys were more likely to be infected with G. lamblia than girls $(18,19)$, which is similar to the present findings. Male was associated with a significantly higher relative risk for the first episode of symptomatic giardiasis.

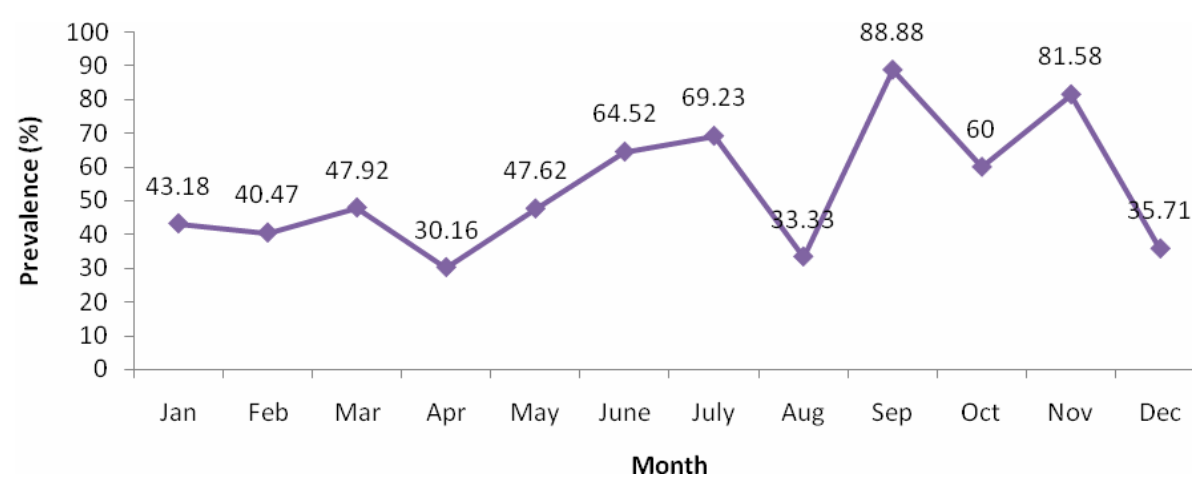

Fig. 2. Monthly prevalence of G. lamblia in symptomatic children by Real Time PCR.

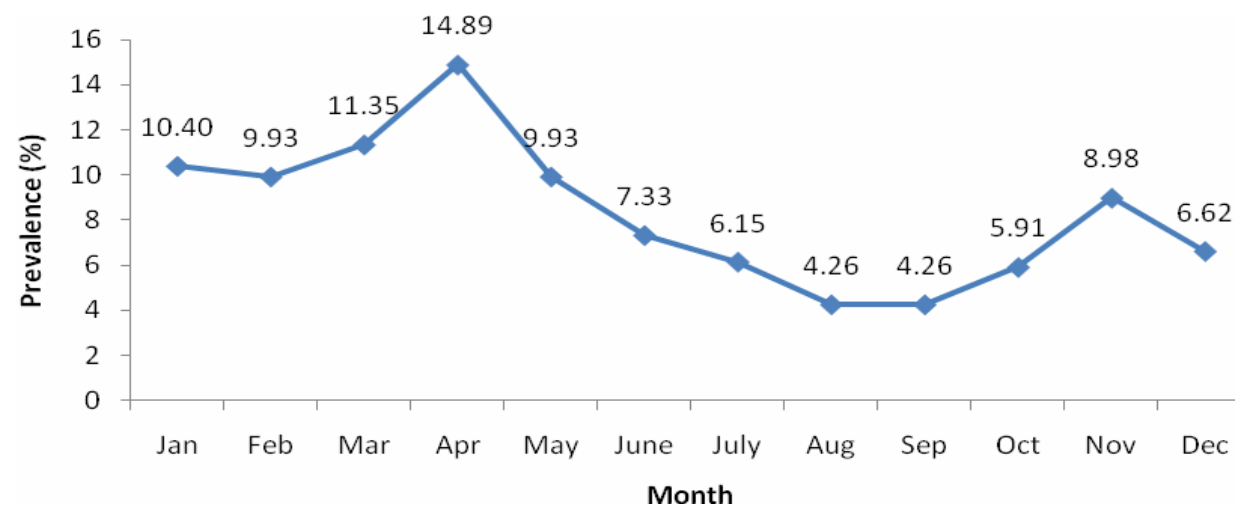

Fig. 3. Monthly prevalence of Giardia lamblia in symptomatic children by ELISA.

The prevalence of G. lamblia infection was highest between 25 and 36 months of age group in asymptomatic children (35.18\%) and between 49 and 60 months of age group in diarrhoeal children $(80.95 \%)$, a finding similar to that of previous studies ${ }^{(10)}$. The possible reasons for this age dependent pattern are probably related to children habits (e.g. sharing things among themselves, putting objects into the mouth, etc.). Another reason for higher infections in children may also be related to the lack of effective immunity and malnutrition $(20,21)$.

In the present investigation, seasonal studies of G. lamblia infection showed the highest prevalence between March and June in asymptomatic samples and between 
September and November in symptomatic samples. The monthly prevalence of $G$. lamblia in symptomatic children by ELISA was found in April (Fig. 3). Haque et al. found similar findings for G. lamblia infection in patients with acute diarrhoea (22).

Diagnosis by microscopy is neither sensitive nor specific. In general pathological laboratories, detection is done usually by simple microscopy where maximum negative results are reported. Though ELISA and PCR are expensive and time consuming methods, they definitely give more accurate results on sensitivity and specificity of the diarrheal parasites. A greater awareness of parasitic contamination of the environment and its impact on health has necessitated the development of better detection methods for G. lamblia.

\section{References}

1. World Health Organization 2005. World Health Report. Making Every Mother and Child Count. Geneva: World Health Organization. pp. 243.

2. Thompson RCA, RM Hopkins and WL Homan 2000. Nomenclature and genetic groupings of Giardia infecting mammals. Parasitol. Today 16: 210-213.

3. Khanum H, SS Khanam, M Sultana, HM Uddin, RC Dhar and SM Islam 2011. Occurrence of Giardia in the effluents of a waste water treatment plant in Dhaka. Bangladesh J. Zool. 39(2): 147-156.

4. Stark D, JL Barratt, SV Hal, D Marriott, J Harkness and JT Ellis 2009. Clinical significance of enteric protozoa in the immuno suppressed human population. Clin. Microbiol. Rev. 22: 634-650.

5. Gardner TB and DR Hill 2001. Treatment of giardiasis. Clin. Microbiol. Rev. 14(1): 114-128.

6. World Health Organization. 1996. The World Health Report -1996, Fighting Disease Fostering Development, Geneva. pp. 143.

7. Nygard K, B Schimmer and O Sobstrad 2006. A large community outbreak of waterborne giardiasis delayed detection in a non-endemic urban area. BMC Public Health. 6: 141-141.

8. Minvielle M, B Pezzani, DM Luca, M Apezteguia and J Basualodo 2004. Epidemiological survey on Giardia sp. and B. hominis in an Argentinian rural community. Korean J. Parasitol. 42: 61-66.

9. Hall A 1994. Giardia infections: Epidemiology and nutritional consequences. In: Giardia: From Molecules to Disease (Thompson RCA, JA Reynoldson and AJ Lymbery). 2nd (eds.), pp. 251-279 Cab International, Wallingford, UK.

10. Haque R, D Mondal, BD Kirkpatrick, S Akther, BM Farr, RB Sack and WA Petri Jr 2003. Epidemiologic and clinical characteristics of acute diarrhoea with emphasis on Entamoeba histolytica infections in preschool children in an urban slum of Dhaka, Bangladesh. Amer. J. Trop. Med. and Hyg. 69: 398-405.

11. Alam MM, M Ilias, MA Siddique, MM Kabir, F Nazib, and GM Khan 2011. Genotype-specific detection of Giardia lamblia in stool samples of diarrhoeal patients in Dhaka, Bangladesh. Dhaka Univ. J. Biol. Sci. 20: 183-189. 
12. Mcglade TR, ID Robertson, AD Elliot and RC Thompson 2003. High prevalence of Giardia detected in cats by PCR. Veterinary Parasitol. 110: 197-205.

13. Nash TE, DA Herrington, and MM Levine 1987. Usefulness of an enzyme-linked immunosorbent assay for detection of Giardia antigen in faeces. J. Clin. Microbiol. 27: 11691171.

14. Aldeen WE, D Hale, AJ Robison and K Carroll 1995. Evaluation of a commercially available ELISA assay for detection of Giardia lamblia in fecal specimens. Diagn. Microbiol. Infect. Dis. 21(2): 77-9.

15. Prasertbun R, Y Sukthana and S Popruk 2012. Real Time PCR: Benefits for detection of mild and asymptomatic Giardia infections. Trop. Med. and Health. 40 (2): 31-35.

16. Ngan PK, NG Khanh, CV Tuong, PP Quy, DN Anh and HT Thuy 1992. Persistent diarrhea in Vietnamese children: A preliminary report. Acta Paediatrica 381:124-126.

17. Verle P, A Kongs, NV De, NQ Thieu, K Depraetere, HT Kim and P Dorny 2003. Prevalence of intestinal parasitic infections in northern Vietnam. Tropical Medicine of International Health 8: 961-964.

18. Ranjan P, UC Ghoshal, R Aggarwal, R Pandey, A Misra, S Naik and SR Naik 2004. Etiological spectrum of sporadic malabsorption syndrome in northern Indian adults at a tertiary hospital. Ind. J. Gastroenterol. 23: 94-98.

19. Dwivedi KK, G Prasad, S Saini, S Mahajan, S Lal and U Krishan 2007. Enteric opportunistic parasites among HIV infected individual: Associated risk factors and immune status. Jap. J. Infect. Dis. 60: 76-81.

20. Khanum H, S Chawdhury and S Sultana 1998. Prevalence of Giardia intestinalis among the children of rural area of Bangladesh. Bang. J. Zool. 26(2): 85-89.

21. Khanum H, R Haque and R Zannat 2000. Prevalence of Giardia lamblia infection in asymptomatic rural children in Mirzapur, Bangladesh. Univ. J. Zool., University of Rajshahi. 19: 79-82.

22. Haque R, D Mondal, A Karim, IH Molla, A Rahim, ASG Faruque, N Ahmad, BD Kirkpatrick, E Houpt, C Snider, and WA Jr Petri 2009. Prospective case-control study of the association between common enteric protozoan parasites and diarrhea in Bangladesh. Clin. Infect. Dis. 48(9): 1191-1197. 